RENAL DISEASE

ASSOCIATED WITH

ENDOCARDITIS

\title{
An insight into renal disease associated with infective endocarditis
}

Authors: A.B. Adeniyi MBBS FWACP, J.D. Nel MBChB MMed (Int) Cert Neph (CMSA)

Division of Nephrology, Department of Medicine, Tygerberg Hospital and University of Stellenbosch

Dr Adeniyi is a visiting fellow from Abuja, Nigeria, currently specializing in Nephrology.

Dr Nel has been a consultant at the Division of Nephrology since 2005

Address for correspondence:

DrJ D Nel

A7 renal unit

Tygerberg Hospital

Tygerberg

7505

Email:

johannel@sun.ac.za

ABSTRACT This review on renal involvement associated with infective endocarditis offers clinicians insight into the pathophysiology behind each major mechanism of the renal disease. It briefly discusses the treatment of the various forms of renal disease, and describes pitfalls in the management of endocarditis that may significantly worsen the renal outcome. A practical approach is provided, based on the timing of onset of the renal disease, the patient's history, and the correct interpretation of various clinical and biochemical parameters.

\section{INTRODUCTION}

Kidney dysfunction and subsequent acute renal failure commonly occur, and is usually multifactorial in patients with infective endocarditis (Table I). The incidence of renal disease in endocarditis varies: a retrospective study in 1998 showed that approximately one-third of patients developed acute renal failure ${ }^{(1)}$, while a recent study in the Western Cape showed renal involvement to occur in $59.6 \%$ of cases. ${ }^{(2)}$ Though the true impact of infective endocarditis as a cause of endstage kidney disease has not been established, it is well known that the outcome may vary from sub-clinical manifestations to a fulminant course. Distinguishing between the various causes requires a thorough history and examination in order to establish the timing of the renal manifestations in relation to the patient's clinical course and treatment. This overview provides the reader with some insight into the various mechanisms, their presentation and expected outcomes, with pointers that will allow the clinician to make an accurate etiological diagnosis, and manage the renal aspects of endocarditis appropriately.

\section{“PRERENAL” FAILURE DUE TO INSUFFICIENT} RENAL PERFUSION, AND ISCHEMIC ACUTE

\section{TUBULAR NECROSIS}

Renal hypoperfusion due to causes such as septic shock, cardiac failure and arrhythmia results in poor effective perfusion of the kidneys and leads to a clinical picture of "prerenal" renal failure ${ }^{(3)}$.A biopsy performed at this stage would reveal nothing but histological normal glomeruli and tubuli ${ }^{(4)}$, despite serum urea and creatinine values reflecting progressively worsening kidney function. The renal medulla is very vulnerable to ischemic injury, and sufficiently prolonged ischemia quickly leads to acute tubular necrosis (ATN). ${ }^{(5)}$ Despite its high oxygen requirements due to intense metabolic activity, it receives only $20 \%$ of total renal blood flow. The medullary oxygen partial pressure is

TABLE I: Mechanisms of renal disease in infective endocarditis

\begin{tabular}{|c|c|}
\hline Pathophysiological mechanisms & Causes \\
\hline $\begin{array}{l}\text { "Prerenal" failure due to insufficient renal } \\
\text { perfusion }\end{array}$ & $\begin{array}{l}\text { Congestive cardiac failure } \\
\text { Cardiac arrhythmias } \\
\text { Hypotensive shock (due to sepsis or } \\
\text { cardiac dysfunction) } \\
\text { Intraoperative cardiac arrest } \\
\text { Prolonged intraoperative hypotension and } \\
\text { ischemia } \\
\text { Altered hemodynamics due to } \\
\text { prostaglandin inhibition by NSAIDS }\end{array}$ \\
\hline Acute tubular necrosis (ATN) & $\begin{array}{l}\text { Ischemic ATN due to insufficient renal } \\
\text { perfusion or NSAIDS } \\
\text { Nephrotoxic ATN due to antibiotics such } \\
\text { as gentamycin, amphotericin B }\end{array}$ \\
\hline Acute interstitial nephritis (AIN) & $\begin{array}{l}\text { Drugs: vancomycin, methicillin, rifampicin, } \\
\text { NSAIDs } \\
\text { Radiocontrast agents }\end{array}$ \\
\hline Circulating immune complex mediated & Endocarditis-associated glomerulonephritis \\
\hline $\begin{array}{l}\text { Embolic phenomena / hematogenous } \\
\text { seeding of infection }\end{array}$ & Renal infarcts and abscesses \\
\hline
\end{tabular}


TABLE 2: Diagnostic parameters to differentiate between causes of renal failure in endocarditis

\begin{tabular}{|c|c|c|c|c|}
\hline Parameters & $\begin{array}{l}\text { Prerenal Renal } \\
\text { Failure }\end{array}$ & $\begin{array}{c}\text { Acute Tubular } \\
\text { Necrosis }\end{array}$ & $\begin{array}{c}\text { Acute Interstitial } \\
\text { Nephritis }\end{array}$ & $\begin{array}{l}\text { Endocarditis- } \\
\text { associated GN }\end{array}$ \\
\hline Time of onset & $\begin{array}{l}\text { At presentation } \\
\text { or during } \\
\text { management }\end{array}$ & $\begin{array}{l}\text { At presentation } \\
\text { or during } \\
\text { management }\end{array}$ & $\begin{array}{c}\text { During } \\
\text { management }\end{array}$ & At presentation \\
\hline $\begin{array}{l}\text { Plasma urea: } \\
\text { creatinine ratio }\end{array}$ & 1:10 or greater & $1: 20$ & $1: 20$ & $1: 20$ \\
\hline Urine Volume & Oliguria & $\begin{array}{l}\text { Oliguria or } \\
\text { Nonoliguria }\end{array}$ & $\begin{array}{l}\text { Oliaguria or } \\
\text { Nonoliguria }\end{array}$ & $\begin{array}{l}\text { Oliguria or } \\
\text { Nonoliguria }\end{array}$ \\
\hline Urine Osmolality & $>450 \mathrm{mosm} / \mathrm{kg}$ & $<350 \mathrm{mosm} / \mathrm{kg}$ & - & - \\
\hline Urine Microscopy & $\begin{array}{l}\text { Normal }+/ \text { - } \\
\text { hyaline casts }\end{array}$ & $\begin{array}{l}\text { Muddy granular } \\
\text { and epithelial cast }\end{array}$ & $\begin{array}{l}\text { White cells, } \\
\text { eosinophils and } \\
\text { white cell casts }\end{array}$ & $\begin{array}{c}\text { Dysmorphic red } \\
\text { cells and red cell } \\
\text { casts }\end{array}$ \\
\hline $\begin{array}{l}\text { Urine } \mathrm{Na} \\
\text { Excretion }\end{array}$ & $<20 \mathrm{meq} / \mathrm{L}$ & $>40 \mathrm{meq} / \mathrm{L}$ & - & - \\
\hline $\begin{array}{l}\text { Fractional } \mathrm{Na} \\
\text { Excretion }\left(\mathrm{FE}_{\mathrm{Na}}\right)\end{array}$ & $<1 \%$ & $>2 \%$ & - & - \\
\hline $\begin{array}{l}\text { Fractional Urea } \\
\text { Excretion }\left(\mathrm{FE}_{\text {urea }}\right)\end{array}$ & $<35 \%$ & $>35 \%$ & - & - \\
\hline $\begin{array}{l}\text { Urine Protein } \\
\text { Estimation }\end{array}$ & $\begin{array}{l}\text { Normal or } \\
<\mid \text { g/day }\end{array}$ & $<2$ g/day & $<2$ g/day & $\begin{array}{l}\text { May be absent } \\
\text { OR up to } 2 g / \text { day }\end{array}$ \\
\hline
\end{tabular}

$\mathrm{Cr}$; Creatinine concentration in mmol/I, BUN; urea concentration in mmoll/, $\mathrm{Na}$; Sodium concentration, FENa: [Urine Na x Plasma Cr / Plasma Na x Urine Cr] x 100, FEurea: [Urine Urea x plasma Crl Plasma Urea $\times$ Urine $\mathrm{Cr}] \times 100$

Adapted from information provided in Lameire N, Van Biesen W, Vanholder R. Acute renal failure. The Lancet 2005; 365: 417-430.

extremely low ${ }^{(5)}$ and the balance between oxygen supply and demand is very delicate. In addition to ischemic stresses, fluid restriction, exposure to radiocontrast media and potentially nephrotoxic drugs or pre-existing chronic kidney disease (CKD) can all act in concert to increase the progression to ATN and worsen the outcome..$^{(3,4)}$

Though it may sometimes be difficult, it is possible to distinguish prerenal renal failure from either ischemic or nephrotoxic ATN by using a set of parameters based on pathophysiological changes in these conditions (Table 2). It is important to note that none of these parameters on its own is sufficient to differentiate between prerenal renal failure and ATN - hence the need to combine as many parameters as are available. Both prerenal renal failure and ATN are heralded by poor urine output or oliguria and azotemia either at presentation or in the course of management. ${ }^{(3,4)}$ While oliguria is universal in prerenal renal failure, ATN may present with oliguria or normal urine volume, especially when due to nephrotoxins (e.g. gentamycin). Renal reabsorption of urea, sodium and water is increased in prerenal renal failure and impaired in ATN, the key difference being preserved tubular function in the former. The normal serum urea: creatinine ratio of 1:20 is preserved in ATN. When underperfused, there is a decrease in tubular flow rate. The subsequent increased reabsorption of urea (a much smaller molecule than creatinine) in intact tubules results in a disproportionate increase in urea relative to creatinine. The result is a urea: creatinine ratio of 1:10 or more in prerenal failure. Microscopic examination of urine in prerenal renal failure is essentially normal, while the classic finding in ATN is muddy brown granular and tubular epithelial cell casts due to sloughing-off of tubular cells into the lumen. In mild nonoliguric ATN without extensive tubular damage, microscopy may reveal only scanty granular or epithelial cast formation or even be normal. ${ }^{(6,7)}$

Careful scrutiny of urine chemistry results may provide useful additional information (Table2). Due to the loss of tubular functions of concentration and dilution, in ATN the urine osmolality will usually approach that of plasma, and sodium will be excreted even in the face of hypoperfusion - with the resulting urinary sodium exceeding $20 \mathrm{meq} / \mathrm{L}$ and a fractional excretion of $>1 \%$. In contrast, with prerenal failure the kidneys compensate by maximally reabsorbing sodium and water. This results in a high urine osmolality (usually $>450$ mosm $/ \mathrm{kg}$ ) and low urine sodium $(<20 \mathrm{mosm} / \mathrm{L})$, with the fractional excretion of sodium less than 1\%. Proteinuria in prerenal renal failure is usually normal and always less than I gram per 24 hours. In ATN proteinuria may be up to 2 grams per 24 hours. Neutrophil gelatinase-associated lipocalin (NGAL), a newer biochemical parameter that might aid earlier detection of ischemic ATN, has recently been described although more studies are needed to validate its value. ${ }^{(8,9)}$ Other possibly useful markers are low molecular weight proteins and brush border enzyme, which is high in ATN and low in prerenal renal failure. Fractional excretion or urea, uric acid and lithium can also be used. ${ }^{(10)}$

With the correction of the prerenal factors responsible, recovery of renal function in prerenal renal failure will usually occur within 48 to 72 hours. In ATN, recovery may take weeks and patients may need renal replacement therapy as support in the interim. Correction of prerenal factors can be as simple as sufficient intravenous fluid therapy or inotropic support, but may entail surgical correction of valvular abnormality or drainage of intracardiac abscesses. Several factors during and after surgery, such as anaesthetic agents, prolonged ischemia resulting from difficult and prolonged surgery, and septic shock, are all associated with poorer patient and renal outcomes. ${ }^{(1,12)}$ 


\section{NEPHROTOXIC ACUTE TUBULAR NECROSIS}

Exposure to potentially nephrotoxic drugs, such as gentamicin, vancomycin and rifampicin, can lead to nephrotoxic ATN or acute interstitial nephritis (AIN). ${ }^{(13,14,15,16)}$ Nephrotoxic ATN is usually dose dependent and occurs through either vasoactive mechanisms (e.g. non-steroidal anti-inflammatory drugs and radiocontrast agent), or direct tubular cell damage (e.g. aminoglycosides).

NSAIDS have little effect on kidney function in normal individuals. However, in patients already compromised by volume depletion, heart failure or pre-existing renal disease, renal perfusion is improved by production of vasodilator prostaglandins as an adaptive mechanism. NSAIDS prevent the synthesis of these prostaglandins by inhibiting cyclooxygenase isoenzymes, thereby decreasing renal blood flow. This precipitous decline leads initially to prerenal azotemia and, if prolonged or severe enough, to ATN. ${ }^{(5)}$

Radiocontrast material commonly used in cardiac catheterizations and computerized tomography (CT) imaging, induce intense vasospasm and also have direct tubulotoxic effects. A gradual deterioration in renal function may be seen from 24 hours after exposure, though oliguria is uncommon. Diabetics with nephropathy, the elderly and patients with pre-existing chronic kidney disease are particularly at risk. ${ }^{(17)}$ Astute clinicians will minimize injury to their patients by reviewing the estimated glomerular filtration rate (GFR) of all patients prior to radiocontrast studies, identifying those at risk, and by considering alternative imaging tests. Standard protective strategies against this form of renal injury include intravenous fluid loading with normal saline 12 hours before the contrast study, and the use of $\mathrm{N}$-acetyl cysteine. ${ }^{(17)}$ Apart from supportive measures, no specific treatment exists once renal injury has occurred.

Aminoglycoside nephrotoxicity is particularly common and tends to manifest while the patient is still on the offending agent - often within 4-5 days from its initiation. Older and female patients are particularly at risk, as well as those with pre-existing renal disease, magnesium, potassium and calcium deficiencies, and hypotensive patients with intravascular volume depletion. ${ }^{(18)}$ The clinical picture is similar to that described with ischemic ATN, but patients are frequently not oliguric.
Despite its inherent nephrotoxicity, aminoglycosides remain a valuable part of the antimicrobial armamentarium. To prevent damage, observant clinicians should monitor their patients' pre-existing renal function and adapt drug doses accordingly. Use of a single daily dose of aminoglicoside where possible is recommended, as well as reducing the treatment course to as short as possible and making intervals between aminoglicoside courses as long as possible. (18) The use of any concurrent potentially nephrotoxic drugs should be avoided. The diagnosis is usually evident from the clinical picture, though when in doubt (and to exclude other causes) a renal biopsy may be performed. Myeloid bodies, seen by electron microscopy, are pathognomonic. Recovery is slower than with typical ATN: serum creatinine takes a median time of 3 weeks to return to baseline, and this may be delayed even further if any other contributory factors to renal injury are present.

\section{ACUTE INTERSTITIAL NEPHRITIS (AIN)}

Drug-induced AIN is not dose-dependent but an idiosyncratic reaction, and recurrence or exacerbation can occur with a second exposure to the same or a related drug. The onset of AIN ranges from three to five days with a second exposure to the same offending agent, to as long as several weeks with a first exposure.(13, 14, 15) The classical features are allergic-type manifestations: fever, a skin rash and eosinophilia occurring together or in isolation. In a review of four different series the occurrence of the triad was found in less than $10 \%$ of cases, while fever, rash and eosinophilia occurred more frequently.(19,20) Other typical findings include acute renal insufficiency characterized by a sudden rise in serum creatinine level that is related to the administration of the offending drug. Urine microscopy may show eosinophiluria, white cells, white cel casts and red cells. An absence of suggestive sediments does not exclude AIN. Daily protein excretion can either be normal or less than Ig; although nephrotic range proteinuria might be present if due to non-steroidal anti-inflammatory drugs (NSAID) or in the presence of other associated conditions that might contribute to the quantity of proteinuria. ${ }^{(14)}$

Renal biopsy is indicated only if there is no response within one week of discontinuation of the offending drug, diagnostic uncertainty or advanced renal failure. ${ }^{(20)}$ Histology typically reveals interstitial oedema and a marked interstitial infiltrate consisting primarily of T-lymphocytes. 
A monocytic infiltrate, eosinophils, plasma cells and granulomas have also been found. Although not specific, a positive Gallium 67 scan be used to distinguish AIN from ATN.(21) Recovery of renal function after discontinuation of the offending agent might be evident within one week in a majority of cases and further evaluation is not necessary in responsive cases.(22) Though no randomized controlled trials are available to show proven benefit, corticosteroids can be used in biopsyproven cases or commenced empirically in cases where biopsy is not deemed suitable. Clinical and histologic indicators of a decreased likelihood of recovery include prolonged renal failure (greater than three weeks), AIN associated with NSAID use, and a biopsy showing interstitial granulomas, interstitial fibrosis, and tubular atrophy. ${ }^{(23,24)}$

\section{ENDOCARDITIS-ASSOCIATED GLOMERULONEPHRITIS}

Patients commonly develop a form of post-infectious glomerulonephritis due to circulating immune-complexes. It may occur in both acute and sub-acute endocarditis. The exact incidence of this entity is not known because of a lack of sufficient prospective studies ${ }^{(25)}$. The prevalence and the type of causal organism associated with glomerulonephritis have varied considerably over time, since the introduction of antibiotic treatment. ${ }^{(26,27,28,29)}$ Renal deterioration is usually evident at presentation and worsens progressively without treatment. It occasionally progresses to end-stage renal failure when undetected or left untreated.

Examination by urinary dipstix usually reveals hematuria with or without proteinuria. Microscopy of the urine typically demonstrates dysmorphic red blood cells. Though not always present, red blood cell casts are considered diagnostic. The development of an overt nephrotic syndrome is unusual, but may occur in up to $30 \%$ of patients with shunt nephritis. ${ }^{(30)}$ Several serological laboratory tests may aid the diagnosis. Elevated circulating immune complexes are demonstrated in up to $90 \%$ of cases, ${ }^{(31,32,33)}$ and a positive rheumatoid factor in 10-70\%. Hypocomplementemia is found in about $68-90 \%$ of diffuse and $60 \%$ of focal glomerulonephritis associated with endocarditis, ${ }^{(25,27)}$ indicating activation of the classic complement pathway. Mixed cryoglobulins are found in $95 \%$ of patients with endocarditis, but correlation with glomerulonephritis has not yet been established. $\left.{ }^{32}, 33,34\right)$ Recent literature describes cases of anti-cytoplasmic antibody (ANCA) positive endocarditis-associated glomerulonephritis, usually presenting with rapidly progressive renal failure. ${ }^{(35-39)}$

The typical glomerular lesions are focal proliferative and diffuse proliferative glomerulonephritis associated with increased cellularity in the mesangial and endothelial portion, with or without crescents. ${ }^{(25-27)}$ Diffuse crescentic glomerulonephritis has also been reported. ${ }^{(39-41)}$

Appropriate antibiotic therapy usually results in recovery of renal function. The recovery may be rapid with return to or near baseline in mild cases, though hematuria and proteinuria may persist for months. The severity of glomerulonephritis is often determined by prolonged disease and delayed commencement of antibiotic treatment.(25) Progression to end-stage renal failure has been associated with crescentic glomerulonephritis and occasionally diffuse proliferative glomerulonephritis, while it is uncommon with focal glomerulonephritis, which usually presents with mild renal failure. ${ }^{(27,42)}$ Treatment of severe cases may require the use of immunosuppressive therapy such as steroids. $(40,41)$ Treatment of isolated cases with plasmapheresis, in addition to antibiotic and steroid therapy, has also been described. ${ }^{(43,44)}$ Little is known about the effect of surgical intervention on the recovery of glomerulonephritis, ${ }^{(40)}$ though correction of valvular lesions may correct other contributory factors to renal failure.

\section{EMBOLIC PHENOMENA AND ABSCESSES}

Renal infarction and abscess formation arise from arterial embolization of vegetation or hematogenously seeded focal infection. These conditions were more common in the pre-antibiotic era, with one study revealing an incidence of $56 \%$ on autopsy. ${ }^{(45)}$ The frequency of embolic events reduced significantly with the advent of antibiotic treatment, though it may still be found in Staphylococcus aureus endocarditis and in cases where antibiotic therapy was delayed. Embolic renal infarcts may be asymptomatic or manifest clinically as flank pain with hematuria and pyuria but rarely causes renal dysfunction.Associated clinical findings include other evidences of embolic phenomena such as Osler's nodes, Roth's spots and Janeway lesions; as well as abscesses in other organs - most commonly the spleen, bowel or brain. No current studies on outcomes are available. 
AN INSIGHT INTO RENAL

DISEASEASSOCIATED

WITH INFECTIVE

ENDOCARDITIS

\section{PUTTING THEORY TO GOOD USE: A PRACTICAL} APPROACH

Appropriate treatment of renal dysfunction can only be offered once the aetiology has been established. Three important factors can guide the astute clinician to the correct diagnosis: the timing of renal manifestations, the patient's concurrent history and the urinary findings (both microscopy and biochemistry). Timing already provides an essential means to distinguish between several causes: endocarditisassociated nephritis is typically present at the time of diagnosis of infective endocarditis, ${ }^{(46)}$ and near its peak of severity just before the institution of appropriate antibiotic therapy, whereas both acute interstitial nephritis and aminoglycoside-induced ATN require at least three to five days and, in the former, up to several weeks of administration of the culprit drug. Renal emboli can occur as late as several months after bacteriologic cure.

The patient's concurrent history can help identify culprit drugs, and reveal the presence of sepsis, shock, or cardiac failure giving rise to renal hypoperfusion, which may in turn lead to either prerenal failure or ischemic ATN. Urinary findings (as described extensively in the preceding paragraphs dealing with prerenal failure and ischemic ATN, and in Table 2) will further assist in coming to the right conclusions. The urinary findings of prerenal failure reflect intact tubular function and will thus show bland urine on microscopy, and highly concentrated urine with a very low sodium concentration, while in ATN the microscopy shows granular casts and an inability to concentrate or dilute urine. The presence of dysmorphic red blood cells and red cell casts is pathognomonic of glomerulonephritis. While proteinuria of up to 2 grams per day may occur in the tubular damage following either ATN or interstitial nephritis, nephrotic range proteinuria should prompt one towards the diagnosis of a glomerulonephritis.

Prompt correction of the factors responsible for either prerenal failure or ATN, along with the initiation of the appropriate antibiotics, remain the cornerstone of therapy. The avoidance of any further renal insults needs to be stressed, and the astute clinician would do well to avoid administering any nephrotoxic drug (or radio contrast) unless no alternative exists. A renal biopsy may be indicated where the cause of renal failure is not apparent, in cases of progressive renal dysfunction despite optimal therapy, or to determine the viability of renal recovery after prolonged failure.

While patients with prerenal failure will recover function rapidly, patients with other forms of renal failure may need weeks to recover. At this stage it remains imperative to carefully document daily intake and output, ensure optimal blood pressure and limit the patient's salt and potassium intake. It is best to involve a nephrologist early in the care and decisions of patients who do not show rapid recovery. Supportive dialysis therapy may be indicated, though the exact timing of initiation of dialysis remains unclear.(47) While most textbooks still state the indications as "symptoms or signs of the uremic syndrome, management of refractory hypervolemia, -kalemia or acidosis, or a serum urea exceeding $35 \mathrm{mmol} / \mathrm{L}$ ", a recent study of 52 units in 23 countries revealed a much more aggressive dialysis strategy in all participants. ${ }^{(48}$ Oliguria or anuria for as little as 12 hours, in the absence of reversible prerenal factors, is now considered by many as a sufficient indication to initiate renal support. ${ }^{(5,47,49)}$ 


\section{REFERENCES:}

I. Conlon PJ, et al. Predictors of prognosis and risk of acute renal failure in bacterial endocarditis. Clin Nephrol 1998; 49:96

2. Koegelenberg C, et al. Infective endocarditis in the Western Cape province of South Africa: a three-year prospective study. QJM 2003;96: 217-225

3. Toto, RD.Approach to the patient with kidney disease. In: Brenner \& Rector's the Kidney Brenner, BM (ed); Saunders International, 2004

4. Brady HR, Brenner BM. Acute renal failure. In: Harrison's principles of Internal Medicine. Kasper DL (ed); McGraw-Hill, 2005

5. Woolfson RG, Hillman K. Causes of acute renal failure. In:Comprehensive clinical nephrology, Ed. Johnson RJ. Feehally j; Mosby international 2000

6. Dixon BS, Anderson RJ. Nonoliguric acute renal failure. Am J Kidney Dis 1985; 6: 71-80

7. Eknoyan G. Renal disorders in hepatic failure (letter). Br Med J 1974; 2: 670

8. Mishra J, Dent C, Tarabishi R, et al. Neutrophil gelatinase-associated lipocalin (NGAL) as a biomarker for acute renal injury after cardiac surgery. Lancet 2005; 365: | 23|- 1238.

9. Herget-Rosenthal $\mathrm{S}$. One step forward in the early detection of acute renal failure. Lancet 2005; 365: I205-1206.

10. Lameire N, Van Biesen W, Vanholder R. Acute renal failure. The Lancet 2005; 365 417-430.

II. Meyake M, Hatta K, Kameyama K et al. Infective endocarditis developing as uremia Intern Med 2005; 44(6): 598-602

12. Chan V, Jamieson WR, Chan F, Germann E. Valve replacement surgery complicated by acute renal failure - predictors of early mortality. J Card Surg 2006; 2 I (2): I 39- I 45.

13. Neilson EG. Pathogenesis and therapy of interstitial nephritis. Kidney Int 1989; 35 1257-1270.

14. Ten RM, Torres VE, Milliner DS, et al. Acute interstitial nephritis: Immunologic and clinical aspects. Mayo Clin Proc 1988; 63: 921-930

15. Clive DM, Stoff JS. Renal syndromes associated with nonsteroidal anti-inflammatory drugs. N Engl J Med 1984; 310:563-572.

16. Wai AO, Lo AM, Abdo A, Marra F.Vancomycin-induced acute interstitial nephritis. Ann Pharmacother 1998; 32(11): I160-1164

17. Barret BJ, Parfrey PS. Preventing nephropathy induced by contrast medium. NEJM 2006: 354:379-386

18. De Broe ME. Renal injury due to environmental toxins, drugs and contrast agents. In: Atlas of Diseases of the kidney. Schrier, Berl \& Bonventre; Current Medicine, Philadelphia, 1999, p II.1-11.16

19. Baker RJ, Pusey CD. The changing profile of acute tubulointerstitial nephritis. Nephrol Dial Transplant 2004; 19:8-I।.

20. Clarkson MR, Giblin L, O'Connell FP, et al. Acute interstitial nephritis: Clinical features and response to corticosteroid therapy. Nephrol Dial Transplant 2004; 19:2778-2783.

21. Linton AL, Richmond JM, ClarkWF, et al. Gallium67 scintigraphy in the diagnosis of acute renal disease. Clin Nephrol 1985; 24:84-87.

22. Buysen JG, Houthoff HJ, Krediet RT, Arisz L. Acute interstitial nephritis: a clinical and morphological study in 27 patients. Nephrol Dial Transplant 1990; 5:94-99.

23. Schwarz A, Krause PH, Kunzendorf $U$, et al. The outcome of acute interstitial nephritis: risk factors for the transition from acute to chronic interstitial nephritis. Clin Nephrol 2000; 54: 179-190.

24. Bhaumik SK, Kher $\mathrm{V}$, Arora P, et al. Evaluation of clinical and histological prognostic markers in drug-induced acute interstitial nephritis. Ren Fail 1996; 18: 97-104.

25. Neugarten J, Baldwin DS. Glomerulonephritis in bacterial endocarditis. Am J Med I984; 77:297-304

26. Bell EJ. The glomerular lesion associated with endocarditis. Am J Pathol 1932; 8: 639-662.

27. Neugarten J, Gallo GR, Baldwin DS. Glomerulonephritis in bacterial endocarditis Am J Med 1984; 5: 37|-379.

28. Siciliano AF, Strabelli TM, Zeigler R et al. Infective endocarditis due to Bartonella spp. and Coxiella burnetii: experience at a cardiology hospital in Sao Paulo, Brazil. Ann NY Acad SCi 2006; 1078: 215-222

29. Mittal BV. Renal lesions in infective endocarditis (an autopsy study of 55 cases).J Postgrad Med 1987;33:193-197.

30. Arze RS, et al. Shunt nephritis: Report of two cases and review of the literature. Clin Nephrol 1983; 19:48

31. Bayer AS, Theofilopolous AN. Immunopathogenetic aspects of infective endocarditis Chest 1990; 97: 204-212.
32. Cabane J. Godeau P, Herman G, et al. Fate of circulating immune complex in glomerulonephritis. Am J Med 1979; 66: 277-282

33. Mohammed I, Ansell BA, Holborow El et al. Circulating immune complexes in subacute infective endocarditis and post-streptococcal glomerulonephritis. J Clin Path 1977; 30 308-31।.

34. Sheargren JN, Tuazon CV, Griffin C, et al. Rheumatoid factor in acute bacterial endocarditis. Arthritis Rheum 1976; 19: 887-890.

35. Soto A, Jorgensen C, Oksman F, Noel LH, Sany J. Endocarditis associated with ANCA. Clin Exp Rheumatol 1994:12:203-204.

36. De Carlo-Souza A, Cunha BA. Streptococcal viridans subacute bacterial endocarditis associated with antineutrophil cytoplasmic autoantibodies (ANCA). Heart \& Lung 2003; 32: | 40-142.

37. Anganco R, Thiru S, Olivieri DBG. Pauci-immune glomerulonephritis associated with bacterial infection. Nephrol Dial Transplant 1993; 8(8): 754-756.

38. Kishimoto N, MoriY,Yamahara H et al. Cytoplasmic antineutrophil cytoplasmic antibody positive pauci-immune glomerulonephritis associated with infectious endocarditis. Clin Nephrol 2006; 66(6): 447-454.

39. Kannan S, Mattoo TK (200I). Diffuse crescentic glomerulonephritis in bacterial endocarditis. Pediatr Nephrol; 16:423-428.

40. Sadikoglu B, Bilge I, Kilicaslan I et al.Crescentic glomerulonephritis in a child with infective endocarditis. Pediatr Nephrol 2006; 21: 867-869.

4I. Koya D, Shibuya K, Kikkewa R, Haneda M. Successful recovery of infective endocarditisinduced rapidly progressive glomerulonephritis by steroid therapy combined with antibiotics: a case report. BMC Nephrology 2004, 5: I 8-22.

42. Boulton-Jones JM, Sissons JGP, Evans DJ, Peters DK. Renal lesions of subacute infective endocarditis. Br Med | 1974; 2: I I- I4

43. Couzi L, Morel D, Deminiere C, Merville P.An unusual endocarditis-induced crescentic glomerulonephritis treated by plasmapheresis. Clin Nephrol 2004; 62 (6): 46I-464.

44. Daimon S, Mizuno $Y$, Fujii $S$ et al. Infective endocarditis-induced crescentic glomerulonephritis dramatically improved by plasmapheresis. Am J Kidney Dis 1998 32(2): 309-313

45. Weinstein L, Rubin RH. Infective endocarditis. Prog Cardiovasc Dis 1973; | 6:239-274.

46. Rose BD. Renal disease in infective endocarditis. Uptodate version 15.1 ww.uptodate.com

47. Palevski PM. Renal replacement therapy: Indications and timing. Crit Care Clin 2005; 21:347-356

48. Uchino $\mathrm{S}$, et al. A multinational multicenter, prospective epidemiological survey of acute renal failure in critical illness:the B.E.S.T kidney study. 27th Annual Scientific Meeting on Intensive Care, Perth, Australia, Oct 2002 (abstract)

49. Uchino S, Bellomo R. Indications for initiation, cessation and withdrawal of renal replacement therapy. In: Intensive Care in Nephrology. Murray PT (ed); Taylor \& Francis, 2006 